\title{
Mechanism of peroxynitrite interaction with cytochrome $c$
}

\author{
Lidia Gębicka ${ }^{凶}$ and Joanna Didik \\ Institute of Applied Radiation Chemistry, Technical University of Łódż, Wróblewskiego 15, \\ 93-590 Łódż, Poland
}

Received: 12 May, 2003; revised: 16 July, 2003; accepted: 11 August, 2003

Key words: cytochrome $c$, peroxynitrite, radiolysis, stopped-flow spectrophotometry

\begin{abstract}
Kinetics of the reaction of peroxynitrite with ferric cytochrome $c$ in the absence and presence of bicarbonate was studied. It was found that the heme iron in ferric cytochrome $c$ does not react directly with peroxynitrite. The rates of the absorbance changes in the Soret region of cytochrome $c$ spectrum caused by peroxynitrite or peroxynitrite/bicarbonate were the same as the rate of spontaneous isomerization of peroxynitrite or as the rate of the reaction of peroxynitrite with bicarbonate, respectively. This means that intermediate products of peroxynitrite decomposition, $\mathrm{OH} / \mathrm{NO}_{2}$ or, in the presence of bicarbonate, $\mathrm{CO}_{3}{ }^{-\cdot} / \mathrm{NO}_{2}$, are the species responsible for the absorbance changes in the Soret band of cytochrome $c$. Modifications of the heme center of cytochrome $c$ by radiolytically produced radicals, $\mathrm{OH}, \mathrm{NO}_{2}$ or $\mathrm{CO}_{3}{ }^{-\cdot}$, were also studied. The absorbance changes in the Soret band caused by radiolytically produced $\mathrm{OH}$ or $\mathrm{CO}_{3}{ }^{-\cdot}$ were much more significant that those observed after peroxynitrite treatment, compared under similar concentrations of radicals. $\mathrm{NO}_{2}$ produced radiolytically did not interact with the heme center of cytochrome $c$. Cytochrome $c$ exhibited an increased peroxidase-like activity after reaction with peroxynitrite as well as with radiolytically produced $\mathrm{OH}, \mathrm{NO}_{2}$ or $\mathrm{CO}_{3}{ }^{-}$' radicals. This means that modification of protein structure: oxidation of amino acids and/or tyrosine nitration, facilitates reaction of $\mathrm{H}_{2} \mathrm{O}_{2}$ with the heme iron of cytochrome $c$, followed by reaction with the second substrate.
\end{abstract}

Peroxynitrite $\left(\mathrm{ONOO}^{-} / \mathrm{ONOOH}\right)$ is a product of a nearly diffusion controlled reaction of nitric oxide ( $\mathrm{NO}$ ) with superoxide anion $\left(\mathrm{O}_{2}{ }^{-\cdot}\right)$. The peroxynitrite anion is stable in alkaline solution, but at physiological $\mathrm{pH}$ it undergoes protonation and rapidly isomerizes to nitrate, partially (about 30\%) via intermediate radical products (Merenyi \& Lind, 1998; Coddington et al., 1999; Gerasimov \& Lymar, 1999; Goldstein et al., 1999):

$$
\mathrm{ONOOH} \rightarrow\left[{ }^{\circ} \mathrm{OH},{ }^{\circ} \mathrm{NO}_{2}\right] \rightarrow \mathrm{NO}_{3}^{-}+\mathrm{H}^{+}
$$

\footnotetext{
${ }^{\bowtie}$ Corresponding author: Lidia Gębicka, phone: (48 42) 631 3160; fax: (48 42) 684 0043; e-mail: lgebicka@mitr.p.lodz.pl
}

Abbreviation: ABTS, 2,2'-azino-bis[ethyl-benzothiazoline-(6)-sulphonic acid]. 
The rate constant of this reaction strongly depends on $\mathrm{pH}$ :

$$
k_{\mathrm{obs}}=k_{1}\left[\mathrm{H}^{+}\right] /\left(K_{\mathrm{a}}+\left[\mathrm{H}^{+}\right]\right)
$$

where $K_{\mathrm{a}}$ - dissociation constant of $\mathrm{ONOOH}$ $\left(\mathrm{p} K_{\mathrm{a}}=6.8\right) ; k_{1}=1.2-1.3 \mathrm{~s}^{-1}$ at $25^{\circ} \mathrm{C}$ (Koppenol et al., 1992; Kissner et al., 1998)

Peroxynitrite is a strong oxidizing and nitrating agent (for recent reviews see Squadrito \& Pryor, 1998; Patel et al., 1999; Radi et al., 2001). Almost all class of molecules can be damaged by peroxynitrite. One of the major targets of peroxynitrite in vivo seems to be $\mathrm{CO}_{2}$. The observed rate constant of this reaction is also $\mathrm{pH}$ dependent:

$$
k_{\mathrm{obs}}=k_{2} /\left(1+\left[\mathrm{H}^{+}\right] / K_{\mathrm{a}}\right)\left(1+K_{\mathrm{a}}^{\prime} /\left[\mathrm{H}^{+}\right]\right)
$$

where $K_{\mathrm{a}}$ - see above; $K_{\mathrm{a}}^{\prime}-$ equilibrium contant for $\mathrm{CO}_{2}$ hydration - dehydration $\left(\mathrm{p} K^{\prime}{ }_{\mathrm{a}}=6.2\right) ; k_{2}=2.3-3.0 \cdot 10^{4} \mathrm{M}^{-1} \mathrm{~s}^{-1}$ at $25^{\circ} \mathrm{C}$ (Lymar \& Hurst, 1995; Goldstein \& Czapski, 1998).

It has been established that the reaction of $\mathrm{ONOO}^{-}$with $\mathrm{CO}_{2}$ forms an adduct that decomposes to yield $30-33 \% \mathrm{CO}_{3}{ }^{-}$and ${ }^{\circ} \mathrm{NO}_{2}$ (Lymar \& Hurst, 1995; Merenyi \& Lind, 1997; Goldstein \& Czapski, 1998):

$$
\begin{gathered}
\mathrm{ONOO}^{-}+\mathrm{CO}_{2} \rightarrow \mathrm{ONOOCO}_{2}^{-} \rightarrow\left[\mathrm{NO}_{2},\right. \\
\left.\mathrm{CO}_{3}^{-\cdot}\right] \rightarrow \mathrm{NO}_{3}^{-}+\mathrm{CO}_{2}
\end{gathered}
$$

However, Koppenol and colleagues reported recently that the yield of radicals in this reaction was at most 10\% (Meli et al., 2002).

Peroxynitrite reacts rapidly with several heme proteins (Floris et al., 1993; Alayash et al., 1998; Minetti et al., 1999; Mehl et al., 1999; Deiber et al., 2000; Exner \& Herold, 2000; Gębicka \& Gębicki, 2000; Bourassa et al., 2001). Some of them catalyze peroxynitrite decomposition (Mehl et al., 1999; Deiber et al., 2000; Gębicka \& Gębicki, 2000).
Cytochrome $c$ is a heme protein which participates in electron transfer processes in biomembranes. The heme group, located in the center of the protein is covalently bound to the polypeptide backbone by Cys-14 and Cys-17. The heme iron is coordinated by His-18 and Met-80. The methionine ligand is dissociated from the heme iron in all nonnative states (Oellerich et al., 2002). Cytochrome $c$, in the native form, displays a very weak peroxidase-like activity (Radi et al., 1991). This activity is enhanced when cytochrome $c$ is partially unfolded or oxidized (Hamachi et al., 1994; Gębicka, 2001; Diederix et al., 2002; Chen et al., 2002).

Recently Cassina et al. (2000) reported nitration of the heme-vicinal Tyr-67 of ferric cytochrome $c$ treated by an excess of peroxynitrite. Peroxynitrite-treated cytochrome $c$ displayed an increased peroxidatic activity (Cassina et al., 2000) and was less active in the electron transfer reaction in mitochondria (Cassina et al., 2000; Nakagawa et al., 2001). It seems, however, that in contrast to the ferrous heme of cytochrome $c$ (Thomson et al., 1995) the ferric heme of cytochrome $c$ is not an important target for peroxynitrite (Cassina et al., 2000; Nakagawa et al., 2001; Pietraforte et al., 2001).

In this study we investigated kinetics of the reaction of peroxynitrite with ferric cytochrome $c$ in the absence and presence of bicarbonate $\left(\mathrm{HCO}_{3}{ }^{-} / \mathrm{CO}_{2}\right)$. As we found that, in contrast to many hemoproteins, absorbance changes of the Soret band of cytochrome $c$ were induced by intermediate radical products of peroxynitrite decomposition, reactions of cytochrome $c$ with radiolytically produced hydroxyl, nitrogen dioxide and carbon trioxide radicals were also studied.

\section{MATERIALS AND METHODS}

Peroxynitrite was prepared by the method described by Pryor et al., (1995). To reduce contamination with unreacted azide, ozona- 
tion was continued for 15 min after obtaining the maximum concentration of peroxynitrite (Uppu et al., 1996). The final concentration of peroxynitrite was about $30 \mathrm{mM}$ as measured spectrophotometrically at $302 \mathrm{~nm}(\varepsilon=1670$ $\mathrm{M}^{-1} \mathrm{~s}^{-1}$ (Hudges \& Nicklin, 1968)). Stock solutions were stored at $-25^{\circ} \mathrm{C}$ and used within 3-4 weeks after synthesis. Nitrite concentration in the stock peroxynitrite solution, measured with Griess reagent (Grisham et al., 1996), was about $2 \mathrm{mM}$ and did not change significantly during storage. Ferric cytochrome $c$ from horse heart was obtained from Sigma. An extinction coefficient of $1.06 \times 10^{5} \mathrm{M}^{-1}$ $\mathrm{cm}^{-1}$ at $410 \mathrm{~nm}$ (Goto et al., 1993) was used for spectrophotometric determination of cytochrome $c$ concentration. All other chemicals were also from Sigma.

The reactions of peroxynitrite with cytochrome $c$, with bicarbonate or with cytochrome $c$ in the presence of bicarbonate were studied using an Applied Photophysics SX-17 stopped-flow spectrophotometer with a $1-\mathrm{cm}$ cell and mixing time $<1 \mathrm{~ms}$. The stock solution of peroxynitrite was diluted to the appropriate concentration with $0.01 \mathrm{M} \mathrm{NaOH}$, cytochrome $c$ and/or bicarbonate were dissolved in $0.2 \mathrm{M}$ phosphate buffer, $\mathrm{pH}$ 7.0. Equal volumes of peroxynitrite and cytochrome $c$ and/or bicarbonate were mixed in the cell and the reaction rate was monitored at 302 and $410 \mathrm{~nm}$.

Autodecomposition of peroxynitrite was monitored at $302 \mathrm{~nm}$ after mixing peroxynitrite solution with $0.2 \mathrm{M}$ phosphate buffer, $\mathrm{pH}$ 7.0. Replicate mixing was performed outside the stopped-flow apparatus to measure the $\mathrm{pH}$ of the reaction mixture. The process of mixing increased the $\mathrm{pH}$ by 0.1 unit.

The peroxidase activity of cytochrome $c$ was assayed by the $2,2^{\prime}$-azino-bis[ethyl-benzothiazoline-(6)-sulphonic acid] (ABTS) method (Childs \& Bardsley, 1975) at pH 7.0 or 7.1 (small $\mathrm{pH}$ changes around $\mathrm{pH} 7$ did not influence the rate of ABTS oxidation).

The reactions of cytochrome $c$ with hydroxyl, nitrogen dioxide or carbon trioxide radicals were initiated by $\gamma$-irradiation of $\mathrm{N}_{2} \mathrm{O}$-satu- rated cytochrome $c$ solution without additives, with $0.1 \mathrm{M} \mathrm{NaNO}_{2}$ or $0.1 \mathrm{M} \mathrm{Na}_{2} \mathrm{CO}_{3}$, respectively, in $1 \mathrm{mM}$ phosphate buffer ( $\mathrm{pH}$ was adjusted to 7.0 ) with a dose rate of $0.025 \mathrm{~J}$ $\mathrm{kg}^{-1}$ per second. Radiolysis of water saturated with $\mathrm{N}_{2} \mathrm{O}$ produces $0.54 \mathrm{~mol} \mathrm{\textrm {J } ^ { - 1 }}$ of hydroxyl radicals (Buxton et al., 1988). Under our experimental conditions the rate of hydroxyl radical formation was $13.5 \mathrm{nM}$ per second. When nitrite is present in $\mathrm{N}_{2} \mathrm{O}$-saturated water, nitrogen dioxide is formed in the following reaction:

$$
{ }^{\circ} \mathrm{OH}+\mathrm{NO}_{2}^{-} \rightarrow \mathrm{OH}^{-}+{ }^{\cdot} \mathrm{NO}_{2}
$$

Similarly, reaction of ${ }^{\circ} \mathrm{OH}$ with carbonate leads to the formation of $\mathrm{CO}_{3}{ }^{-}$:

$$
\mathrm{OH}+\mathrm{CO}_{3}^{2-} \rightarrow \mathrm{OH}^{-}+\mathrm{CO}_{3}^{-\cdot}
$$

Under conditions where concentrations of these salts are in excess of the concentration of ${ }^{\circ} \mathrm{OH}$, the yield of formation of ${ }^{\circ} \mathrm{NO}_{2}$ and $\mathrm{CO}_{3}{ }^{-\cdot}$ should be the same as the yield of ${ }^{\circ} \mathrm{OH}$

Absorption spectra and kinetic measurements in long-time regime were taken on a Hewlett-Packard 8452A diode-array spectrophotometer.

All kinetic measurements were carried out at $24 \pm 0.5^{\circ} \mathrm{C}$. Water from MilliQ Plus was used throughout.

\section{RESULTS AND DISCUSSION}

We measured the time-course of peroxynitrite decomposition in the absence and in the presence of cytochrome $c$ at $\mathrm{pH} 7.1$ under conditions when peroxynitrite was in excess. In both cases peroxynitrite decomposed with a rate constant of $0.4 \pm 0.05 \mathrm{~s}^{-1}$ (not shown). This means that cytochrome $c$ does not catalyze decomposition of peroxynitrite. We checked that addition of an up to 70-fold excess of peroxynitrite to cytochrome $c$ did not result in measurable changes of absorbance in 
the Soret band of cytochrome $c$, whereas larger excess of the oxidant led to a decrease of the intensity of the Soret peak. We measured the kinetics of the absorbance changes in the Soret region of cytochrome $c(410 \mathrm{~nm})$ induced by different amounts of peroxynitrite and found that the rate of the absorbance changes at $410 \mathrm{~nm}$ was the same as the rate of spontaneous peroxynitrite decay, but the yield of bleaching increased with the increase of peroxynitrite concentration (Fig. 1). When

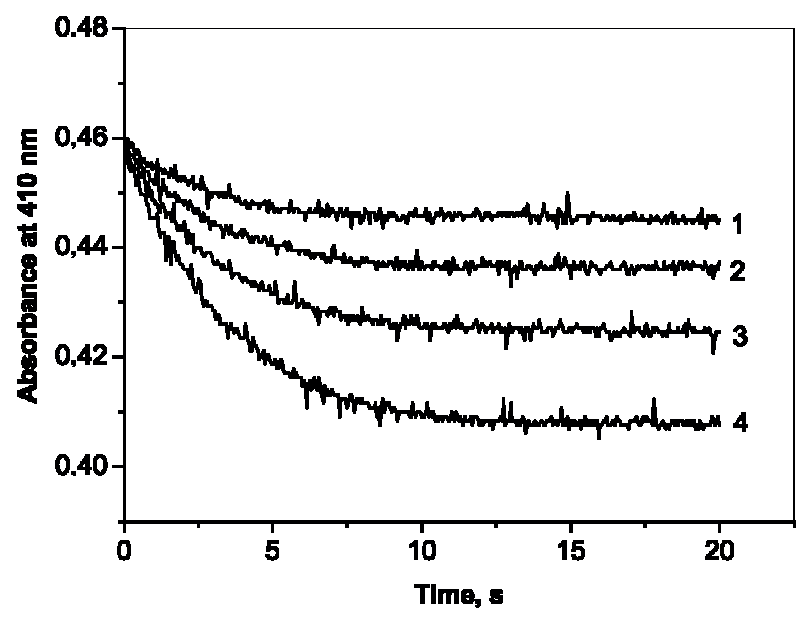

Figure 1. Absorbance changes in the Soret band of cytochrome $c(4.8 \mu \mathrm{M})$ during the reaction with peroxynitrite at a concentration:

1, $0.49 \mathrm{mM}$; 2, $0.98 \mathrm{mM} ; 3,1.46 \mathrm{mM}$ and 4, $2.44 \mathrm{mM}, \mathrm{pH}$ $=7.1$.

peroxynitrite was in a 1000-fold excess over cytochrome $c$, the decrease of absorbance at $410 \mathrm{~nm}$ was about $25 \%$. These results suggest that intermediate products of $\mathrm{ONOOH}$ decomposition ( $\mathrm{OH}$ and/or ${ }^{\circ} \mathrm{NO}_{2}$ ) are the species responsible for the absorbance changes of the Soret band of cytochrome $c$.

Similar experiments were done in the presence of an excess of bicarbonate. From the slope of the plot describing the dependence of the pseudo-first order rate constant of peroxynitrite decomposition on the concentration of bicarbonate at $\mathrm{pH} 7.1, k_{\mathrm{obs}}$ was calculated to be $885 \mathrm{M}^{-1} \mathrm{~s}^{-1}$ (not shown). The absorbance changes in the Soret band of cytochrome $c$ caused by peroxynitrite/bicarbonate were significantly faster than those caused by peroxynitrite alone and depended on the concentration of bicarbonate. From the slope of the plot of the pseudo-first order rate constant of the Soret band bleaching of cytochrome $c$ versus bicarbonate concentration, the second order rate constant equal to $900 \mathrm{M}^{-1} \mathrm{~s}^{-1}$ was obtained (Fig. 2). This value

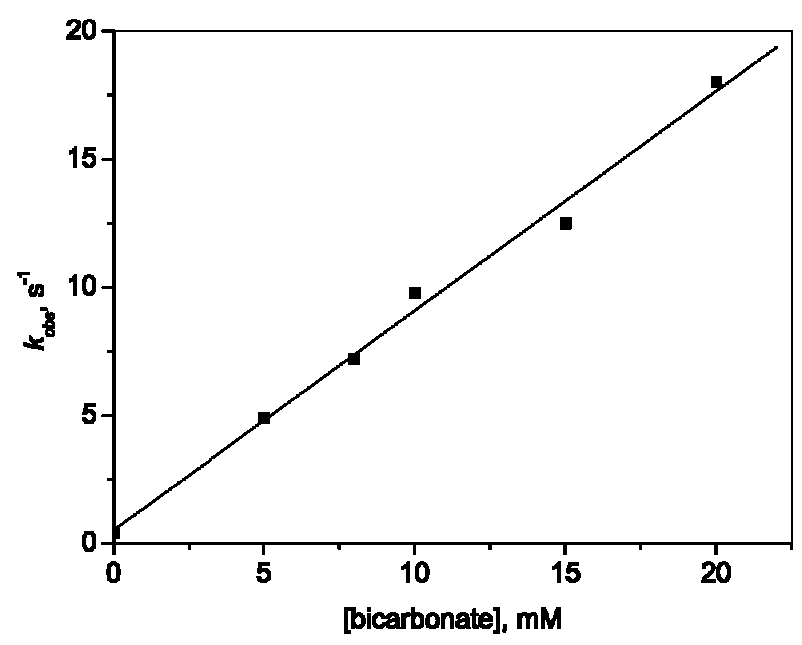

Figure 2. The pseudo-first order rate constant of the Soret band bleaching of cytochrome $c$ versus bicarbonate concentration. [cytochrome $c$ ] = $4.25 \mu \mathrm{M}$, [peroxynitrite] $=0.5 \mathrm{mM}, \mathrm{pH}=7.1$.

is close to the rate constant of the reaction of peroxynitrite with bicarbonate at $\mathrm{pH}$ 7.1. This means that the rate-determining step in the reaction(s) leading to the decrease of intensity of the Soret band of cytochrome $c$ by peroxynitrite/bicarbonate is the formation of the radical pair ${ }^{\circ} \mathrm{NO}_{2} / \mathrm{CO}_{3}{ }^{-\cdot}$. The yield of bleaching of the Soret band by peroxynitrite/bicarbonate was comparable to that caused by the same amount of peroxynitrite alone.

We found, in accordance with Cassina et al. (2000), that the peroxidatic activity of cytochrome $c$ treated with peroxynitrite increased with the increase of the concentration of peroxynitrite. When peroxynitrite was in an almost 1000-fold excess, we observed an about threefold increase in the peroxidase-like activity of cytochrome $c$ (Table 1). Cytochrome $c$ incubated with decomposed peroxynitrite (added to the $0.2 \mathrm{M}$ buffer $5 \mathrm{~min}$. prior to reaction with cytochrome $c$ ) displayed as low peroxidatic activity as the native protein. 
The increase of the peroxidatic activity of cytochrome $c$ treated, prior to activity measurements, with peroxynitrite/bicarbonate (bicarbonate was in excess relative to peroxynitrite) was lower than that observed for cytochrome $c$ modified with peroxynitrite alone (Table 1). We checked that bicarbonate hances the yield of peroxynitrite-induced nitration (Gow et al., 1996; Yiermilov et al., 1996; Lemercier et al., 1997). Our results showed that peroxynitrite in the absence and in the presence of bicarbonate caused similar absorbance changes in the Soret band of cytochrome $c$, whereas a higher increase of

Table 1. Peroxidatic activity of cytochrome $c$, modified by several reactants, measured as the rate of ABTS oxidation at $700 \mathrm{~nm}$.

[cytochrome $c$ ] $=2.7 \mu \mathrm{M} ;[$ ABTS $]=9 \mathrm{mM} ;\left[\mathrm{H}_{2} \mathrm{O}_{2}\right]=5 \mathrm{mM}$.

\begin{tabular}{|c|c|}
\hline Additive & $\begin{array}{c}\text { Rate of ABTS oxidation, } \\
\mu \mu \mathrm{M} / \min \end{array}$ \\
\hline No additive & 5.8 \\
\hline $0.5 \mathrm{mM}$ peroxynitrite & 8.5 \\
\hline $1.5 \mathrm{mM}$ peroxynitrite & 11.0 \\
\hline $2.3 \mathrm{mM}$ peroxynitrite & 17.3 \\
\hline $0.5 \mathrm{mM}$ peroxynitrite $+20 \mathrm{mM}$ bicarbonate & 7.0 \\
\hline $1.5 \mathrm{mM}$ peroxynitrite $+20 \mathrm{mM}$ bicarbonate & 8.2 \\
\hline $2.5 \mathrm{mM}$ peroxynitrite $+20 \mathrm{mM}$ bicarbonate & 10.2 \\
\hline $49 \mu \mathrm{M}^{\circ} \mathrm{OH}$ & 125.6 \\
\hline $73 \mu \mathrm{M}{ }^{\bullet} \mathrm{OH}$ & 120.9 \\
\hline $97 \mu \mathrm{M}{ }^{\circ} \mathrm{OH}$ & 118.9 \\
\hline $73 \mu \mathrm{M} \cdot \mathrm{NO}_{2}$ & 7.9 \\
\hline $97 \mu \mathrm{M}^{\bullet} \mathrm{NO}_{2}$ & 8.9 \\
\hline $49 \mu \mathrm{M} \mathrm{CO}_{3} \cdot$ & 101.4 \\
\hline $73 \mu \mathrm{MCO}_{3}^{\bullet}$ & 109.0 \\
\hline $97 \mu \mathrm{M} \mathrm{CO}_{3} \cdot$ & 101.7 \\
\hline
\end{tabular}

itself, when present in reaction medium, did not influence the peroxidatic activity of native cytochrome $c$.

It has been suggested that the increase of peroxidatic activity of peroxynitrite-treated cytochrome $c$ is related to nitration of Tyr-67, because cytochrome $c$ pretreated with tetranitromethane (a nitrating agent) becomes more sensitive to $\mathrm{H}_{2} \mathrm{O}_{2}$-mediated inactivation (Cassina et al., 2000). On the other hand, it was shown that only a small fraction of nitrogen dioxide formed during peroxynitrite decomposition was able to nitrate tyrosine residues in cytochrome $c$ (Cassina et al., 2000; Nakagawa et al., 2001). It is known that the presence of bicarbonate in the system en- the peroxidatic activity of cytochrome $c$ was observed after its reaction with peroxynitrite alone (Table 1). This means that the increase of the peroxidatic activity of cytochrome $c$ after peroxynitrite treatment is not only due to tyrosine nitration but also to oxidation of other amino-acid residues. This leads to such a modification of protein structure which facilitates the reaction of $\mathrm{H}_{2} \mathrm{O}_{2}$ with heme iron of cytochrome $c$, followed by reaction with the assay substrate (ABTS).

In order to check what is the role of each of the radical intermediates in bleaching of the Soret band of cytochrome $c$ and in the increase of the peroxidatic activity of this protein, we analyzed the absorption spectra and 
peroxidatic activity of cytochrome $c$ after reaction with radiolytically generated hydroxyl, nitrogen dioxide or carbon trioxide radicals.

We found that under conditions when ${ }^{\circ} \mathrm{OH}$

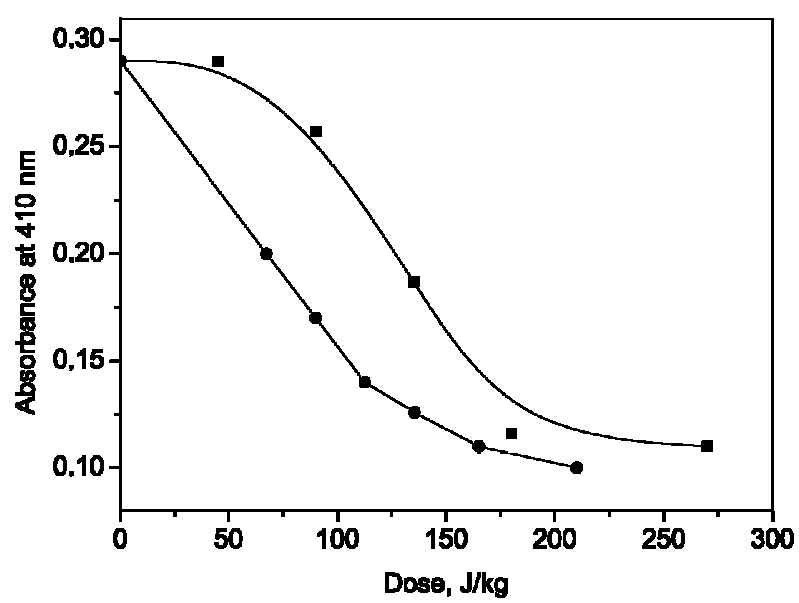

Figure 3. Absorbance changes in the Soret band of cytochrome $c(2.7 \mu \mathrm{M})$ after the reaction with radiolytically produced $\mathrm{OH}(\square)$ or $\mathrm{CO}_{3}{ }^{-\cdot}(\mathrm{O}), \mathrm{pH}$ $=7.0$.

or $\mathrm{CO}_{3}{ }^{-\cdot}$ radicals were the reactive species, the intensity of the Soret band of cytochrome $c$ decreased with the dose (Fig. 3). The faster decrease of cytochrome $c$ absorbance at 410 $\mathrm{nm}$ caused by $\mathrm{CO}_{3}{ }^{-}$may be explained by the more selective action of $\mathrm{CO}_{3}{ }^{-}$than ${ }^{\circ} \mathrm{OH}$ radicals. Hydroxyl radicals react with all amino acids with rate constants higher than $10^{7} \mathrm{M}^{-1}$ $\mathrm{s}^{-1}$ (Buxton et al., 1988) and hence the aminoacid residues located on the surface of the protein are primary targets for ${ }^{\circ} \mathrm{OH}$ attack. Hydroxyl radicals add to aromatic, or abstract $\mathrm{H}$-atom from aliphatic amino-acid residues. Then, transfer of the radical site to the inner part of the protein molecule may take place. In the case of some hemoproteins (among others, cytochrome $c$ ) redox transformation of the heme center was observed as a result of OH-induced radical transfer processes (Simic \& Taub, 1977; Whitburn et al., 1982; Gębicka \& Gębicki, 1992). Oxidation of proteins by $\mathrm{CO}_{3}{ }^{-\cdot}$ is expected to mainly concern tryptophan, cysteine, tyrosine and methionine residues (Neta et al., 1988), i.e. the residues located in the vicinity of the heme group of cytochrome $c$ (Yeh et al., 1998; Cassina et al., 2000). On the other hand, ${ }^{\circ} \mathrm{NO}_{2}$ radicals formed under our experimental conditions did not cause any absorption changes in the Soret region of cytochrome $c$.

The peroxidatic activity of cytochrome $c$ irradiated under conditions when $\mathrm{OH}$ or $\mathrm{CO}_{3}{ }^{-}$ were formed increased significantly. For example, the peroxidase-like activity of cytochrome $c$ treated with $73 \mu \mathrm{M}{ }^{\circ} \mathrm{OH}$ or $\mathrm{CO}_{3}{ }^{-}$increased about 21- and 19-fold, respectively. After the same time of irradiation, the peroxidatic activity of cytochrome $c$ exposed to $\mathrm{NO}_{2}$ radicals increased only 1.5 -fold. Nitrogen dioxide is known to oxidize cysteine, tryptophan and tyrosine. In the case of tryptophan and tyrosine, the rate constant of the reaction with ${ }^{\circ} \mathrm{NO}_{2}$ is about two to three orders of magnitude lower than with $\mathrm{CO}_{3}{ }^{-}$and ${ }^{\circ} \mathrm{OH}$ (Buxton et al., 1988; Neta et al., 1988). On the other hand, the rate of dimerization of ${ }^{\circ} \mathrm{NO}_{2}$ is of the order of $10^{8} \mathrm{M}^{-1} \mathrm{~s}^{-1}$ (Neta et al.,1988) and, as a consequence, the protein damage caused by ${ }^{\circ} \mathrm{NO}_{2}$ should be significantly lower than that caused by the same concentration of $\mathrm{CO}_{3}{ }^{-\cdot}$ or ${ }^{\circ} \mathrm{OH}$. It has been shown (Prütz et al., 1985) that tyrosine is nitrated in the presence of ${ }^{\circ} \mathrm{NO}_{2}$. In the first step phenoxyl radicals are formed, which then react further with ${ }^{\circ} \mathrm{NO}_{2}$ to form nitrotyrosine. It should be stressed that the nitrating power of nitrogen dioxide is significantly enhanced in the presence of ${ }^{\circ} \mathrm{OH}$ and $\mathrm{CO}_{3}{ }^{-}$. This is due to the fact that ${ }^{\circ} \mathrm{OH}$ and $\mathrm{CO}_{3}{ }^{-}$very quickly oxidize tyrosine to phenoxyl radical, which then recombines with $\mathrm{NO}_{2}$ with a diffusion-controlled rate constant (Prütz et al., 1985; Augusto et al., 2002).

The increase of the peroxidatic activity of cytochrome $c$ caused by radiolytically produced ${ }^{\circ} \mathrm{OH}$ or $\mathrm{CO}_{3}{ }^{-}$is much more significant than that observed after peroxynitrite treatment (more than $300 \mu \mathrm{M}{ }^{\circ} \mathrm{OH}$ should be formed during decomposition of $1 \mathrm{mM}$ peroxynitrite - see above). This means that modification of the cytochrome $c$ molecule by ' $\mathrm{OH}$ and $\mathrm{CO}_{3}{ }^{-\cdot}$ radicals produced homoge- 
neously during water radiolysis is more pronounced than that caused by radicals formed during decomposition of peroxynitrite under our experimental conditions. In the latter case, ${ }^{\circ} \mathrm{OH} /{ }^{\circ} \mathrm{NO}_{2}$ or $\mathrm{CO}_{3}{ }^{-\cdot} /{ }^{\circ} \mathrm{NO}_{2}$ radicals are formed in a cage, and even after escape, some of them may recombine. Additionally, a fraction of ${ }^{\circ} \mathrm{OH}$ or $\mathrm{CO}_{3}{ }^{-}$radicals produced during peroxynitrite decomposition may react with nitrite (a contaminant presents in peroxynitrite solution). Thus the concentration of ${ }^{\circ} \mathrm{OH}$ and $\mathrm{CO}_{3}{ }^{-}$radicals which attack the cytochrome $c$ molecule is probably much smaller than that estimated from peroxynitrite concentration.

Summing up, our results show that, in contrast to many other hemoproteins, the heme iron in cytochrome $c$ does not react directly with peroxynitrite. Intermediate radical prodcts of peroxynitrite decomposition, $\cdot \mathrm{OH} / \mathrm{NO}_{2}$, or in the presence of bicarbonate, $\mathrm{CO}_{3}{ }^{-\cdot} / \mathrm{NO}_{2}$, are the species responsible for the absorbance changes in the Soret region of cytochrome $c$. These changes probably reflect structural modifications in the vicinity of the heme, although damage of the heme center by $\mathrm{OH}$ or $\mathrm{CO}_{3}{ }^{-\cdot}$ is also possible. It seems that nitrogen dioxide does not react with the heme iron of cytochrome $c$. Peroxynitrite treated cytochrome $c$ exhibits an increased peroxidase-like activity. This means that modification of protein structure (oxidation of amino acids and/or tyrosine nitration) facilitates reaction of $\mathrm{H}_{2} \mathrm{O}_{2}$ with the heme iron of cytochrome $c$.

\section{R E F E R E N C E S}

Alayash AI, Ryan BA, Cashon RE. (1998) Peroxynitrite-mediated heme oxidation and protein modification of native and chemically modified hemoglobins. Arch Biochem Biophys.; 349: 65-73.

Augusto O, Bonini MG, Amanso AM, Linares E, Santos CCX, De Menezes SL. (2002) Nitrogen dioxide and carbonate radical anion: two emerging radicals in biology. Free Radical Biol Med.; 32: 841-59.

Bourassa JL, Ives EP, Marqueling AN, Shimanovich R, Groves JT. (2001) Myoglobin catalyzes its own nitration. J Am Chem Soc.; 123: $5142-3$.

Buxton GV, Greenstock CL, Helman WP, Ross AB. (1988) Critical review of rate contants for reactions of hydrated electrons, hydrogen atoms and hydroxyl radicals ( ${ }^{\circ} \mathrm{OH} / \mathrm{O}^{-}$) in aqueous solution. J Phys Chem Ref Data.; 17: 513-886.

Cassina AM, Hodara R, Souza JM, Thomson L, Castro L, Ischiropoulos H, Freeman BA, Radi R. (2000) Cytochrome $c$ nitration by peroxynitrite. J Biol Chem.; 275: 21409-15.

Chen Y-R, Deterding LJ, Sturgeon BE, Tomer KB, Mason RP. (2002) Protein oxidation of cytochrome $c$ by reactive halogen species enhances its peroxidase activity. $J$ Biol Chem.; 277: 29781-91.

Childs RE, Bardsley WG. (1975) The steady-state kinetics of peroxidase with 2,2'-azino-di-(3-ethyl-benzthiazoline-6-sulphonic acid) as chromogen. Biochem J.; 145: 93-103.

Coddington JW, Hurst JK, Lymar SV. (1999) Hydroxyl radical formation during peroxynitrous acid decomposition. $J A m$ Chem Soc.; 121: 2438-43.

Deiber A, Herold S, Schöneich C, Namgaladze D, Peterson JA, Ullrich V. (2000) Nitration and inactivation of cytochrome P450(BM-3) by peroxynitrite - Stopped-flow measurements prove ferryl intermediates. Eur $J$ Biochem.; 267: 6729-39.

Diederix REM, Ubbink M, Canters GW. (2002) Peroxidase activity as a tool for studying the folding of $c$-type cytochromes. Biochemistry.; 41: 13067-77.

Exner M, Herold S. (2000) Kinetic and mechanistic studies of the peroxynitrite-mediated oxidation of oxymyoglobin and oxyhemoglobin. Chem Res Toxicol.; 13: 287-93. 
Floris R, Piersma R, Yang G, Jones P, Wever R. (1993) Interaction of myeloperoxidase with peroxynitrite. Eur J Biochem.; 215: 767-75.

Gerasimov OV, Lymar SV. (1999) The yield of hydroxyl radical from the decomposition of peroxynitrous acid. Inorg Chem.; 38: 4317-21.

Gębicka L, Gębicki JL. (1992) Redox transformations in peroxidases studied by pulse radiolysis technique. Radiat Phys Chem.; 39: $113-6$.

Gębicka L. (2001) Peroxidase-like activity of cytochrome $c$ in the presence of anionic surfactants. Res Chem Intermed.; 27: 717-23.

Gębicka L, Gębicki JL. (2000) Reactions of heme peroxidases with peroxynitrite. IUBMB Life.; 49: 11-5.

Goldstein S, Czapski G. (1998) Formation of peroxynitrate from the reaction of peroxynitrite with $\mathrm{CO}_{2}$ : Evidence for carbonate radical production. $J$ Am Chem Soc.; 120: 3458-63.

Goldstein S, Meyerstein D, van Eldik R, Czapski G. (1999) Peroxynitrous acid decomposes via homolysis: evidence from high-pressure pulse radiolysis. J Phys Chem A.; 103: 6587-90.

Goto Y, Hagihara Y, Hamada D, Hoshino M, Nishi I. (1993) Acid-induced unfolding and refolding transitions of cytochrome c: A three-state mechanism in $\mathrm{H}_{2} \mathrm{O}$ and $\mathrm{D}_{2} \mathrm{O}$. Biochemistry.; 32: 11878-85.

Gow A, Duran D, Thom SR, Ischiropoulos H. (1996) Carbon dioxide enhancement of peroxynitrite-mediated protein tyrosine nitration. Arch Biochem Biophys.; 333: 42-8.

Grisham MB, Johnson GG, Lancaster Jr JR. (1996) Quantitation of nitrate and nitrite in extracellular fluids. Methods Enzymol.; 268: 237-46.

Hamachi J, Fujita A, Kunitake T. (1994) Enhanced N-demethylase activity of cytochrome $c$ bound to a phosphate-bearing synthetic bilayer membrane. J Am Chem Soc.; 116: 8811-2.
Hudges MN, Nicklin HG. (1968) The chemistry of pernitrites. Part I: Kinetics of decomposition of pernitrous acid. J Chem Soc.; 450-2.

Kissner R, Nauser T, Bugnon P, Lye PG, Koppenol WH. (1998) Formation and properties of peroxynitrite as studied by laser flash photolysis, high-pressure stopped-flow technique, and pulse radiolysis. Chem Res Toxicol.; 10: 1285-92.

Koppenol WH, Moreno JJ, Pryor WA, Ischiropoulos H, Beckman JS. (1992)

Peroxynitrite, a cloaked oxidant formed by nitric oxide and superoxide. Chem Res Toxicol.; 5: $834-42$.

Lemercier JN, Padmaja S, Cueto R, Squadrito GL, Uppu RM, Pryor WA. (1997) Carbon dioxide modulation of hydroxylation and nitration of phenol by peroxynitrite. Arch Biochem Biophys.; 345: 160-70.

Lymar SV, Hurst JK. (1995) Rapid reaction between peroxynitrite ion and carbon dioxide: implications for biological activity. $J$ Am Chem Soc.; 117: 8867-8.

Mehl M, Daibler A, Herold S, Shoun H, Ullrich V. (1999) Peroxynitrite reaction with heme protein. Nitric Oxide.; 3: 142-52.

Meli R, Nauser T, Latal P, Koppenol WH. (2002) Reaction of peroxynitrite with carbon dioxide: intermediates and determination of the yield of $\mathrm{CO}_{3}{ }^{-}$and ${ }^{\circ} \mathrm{NO}_{2} . J$ Biol Inorg Chem.; 7: 31-6.

Merenyi G, Lind J. (1997) Thermodynamics of peroxynitrite and its $\mathrm{CO}_{2}$ adduct. Chem Res Toxicol.; 10: 1216-20.

Merenyi G, Lind J. (1998) Free radical formation in the peroxynitrous acid $(\mathrm{ONOOH})$ /peroxynitrite $\left(\mathrm{ONOO}^{-}\right)$system. Chem Res Toxicol.: 11: 243-6.

Minetti M, Scorza G, Pietraforte D. (1999) Peroxynitrite induces long-lived tyrosyl radical(s) in oxyhemoglobin of red blood cells through a reaction involving $\mathrm{CO}_{2}$ and ferryl species. Biochemistry.; 38: 2078-87.

Nakagawa H, Ohshima Y, Takusagawa M, Ikota N, Takahashi Y, Shimizu S, Ozawa T. (2001) Functional modification of cytochrome $c$ by 
peroxynitrite in an electron transfer reaction. Chem Pharm Bull.; 49: 1547-54.

Neta P, Huie RE, Ross AB. (1988) Rate constants for reactions of inorganic radicals in aqueous solution. J Phys Ref Data.; 17: 1027-284.

Oellerich S, Wackerbarth H, Hildebrandt P. (2002) Spectroscopic characterization of nonnative conformational states of cytochrome $c$. J Phys Chem B.; 106: 6566-80.

Patel RP, McAndrew J, Sellak H, White CR, Jo H, Freeman BA, Darley-Usmar VM. (1999) Biological aspects of reactive nitrogen species. Biochim Biophys Acta.; 1411: 385-400.

Pietraforte D, Salzano AM, Scorza G, Marino G, Minetti M. (2001) Mechanism of peroxynitrite interaction with ferric hemoglobin and identification of nitrated tyrosine residues. $\mathrm{CO}_{2}$ inhibits heme-catalyzed scavenging and isomerization. Biochemistry.; 40: 15300-9.

Prütz A, Mönig H, Butler J, Land EJ. (1985) Reactions of nitrogen dioxide in aqueous model systems: oxidation of tyrosine units in peptides and proteins. Arch Biochem Biophys.; 243: 125-34.

Pryor WA, Cueto R, Jin X, Koppenol WH, Ngu-Schwemlein M, Squadrito GL, Uppu PL, Uppu MR. (1995) A practical method for preparing peroxynitrite solutions of low ionic strength and free of hydrogen peroxide. Free Radical Biol Med.; 18: 75-83.

Radi R, Peluffo G, Alvarez MN, Navillat M, Cayota A. (2001) Unraveling peroxynitrite formation in biological systems. Free Radical Biol Med.; 30: 463-88.
Radi R, Thomson L, Rubbo H, Prodanov E. (1991) Cytochrome c-catalyzed oxidation of organic molecules by hydrogen peroxide. Arch Biochem Biophys.; 288: 112-7.

Simic MG, Taub IA. (1977) Mechanisms of interand intra-molecular electron transfer in cytochromes. Faraday Disc Chem Soc.; 63: $270-8$.

Squadrito GL, Pryor WA. (1998) Oxidative chemistry of nitric oxide: the roles of superoxide, peroxynitrite and carbon dioxide. Free Radical Biol Med.; 25: 392-403.

Thomson L, Trujillo M, Telleri R, Radi R. (1995) Kinetics of cytochrome $c^{2+}$ oxidation by peroxynitrite: implications for superoxide measurements in nitric oxide-producing biological systems. Arch Biochem Biophys.; 319: 491-7.

Uppu RM, Squadrito GL, Cueto R, Pryor WA. (1996) Synthesis of peroxynitrite by azide-ozone reaction. Methods Enzymol.; 269: 311-21.

Whitburn KD, Shieh JJ, Sellers RM, Hoffman MZ, Taub IA. (1982) Redox transformations in ferrimyoglobin induced by radiation-generated free radicals in aqueous solution. J Biol Chem.; 257:, 1860-9.

Yeh S-R, Han S, Rousseau DL. (1998) Cytochrome $c$ folding and unfolding: A biphasic mechanism. Acc Chem Res.; 31: 727-36.

Yermilov V, Yoshie Y, Rubio J, Ohshima H. (1996) Effects of carbon dioxide/bicarbonate on induction of DNA single-strand breaks and formation of 8-nitroguanine, 8-oxoguanine and base-propenal mediated by peroxynitrite. FEBS Lett.; 399: 67-70. 